\title{
The Research about Expected Hospital Management in Gynecology area based on the Medical Information Record of a University Hospital
}

\author{
Kim Kwang Hwan ${ }^{1^{*}}$ \\ ${ }^{1}$ Department of Hospital Management Konyang University \\ 일개 대학병원 의무기록정보 통계를 활용한 산부인과 병원경영 \\ 예측에 관한연구 \\ 김광환 ${ }^{*}$ \\ ${ }^{1}$ 건양대학교 병원관리학과
}

\begin{abstract}
This research is based on the medical information record of a university hospital on analysis of outpatients, inpatients and delivery related information in gynecology area. The result of application having analysis of patients as basic material for hospital management is as follows. The number of new patients in average was 140.9 , and as the year passes by, it seemed to decrease noticeably $(\mathrm{p}=0.000)$. In the first year (2001) the number was only 212.6 , but increased to 140 by the year of 2007 , showing increase of 80.9 . The actual number of patients in the hospital was 124.6 in average and it showed noticeable decrease after each year $(p=0.000$ ), from 144.6 patients on the first year 2001 , to 104.8 patients in 2007 , showing approximately 40 patients decreased. Multiple regression analysis was performed having independent variables as characteristics of patients and cause of delivery related factors, and dependent variables as the number of patients in the hospital. According to analysis, the cause of affecting the number of patients in the hospital was selected as the number of new patients, the number of delivery per year. The reliability rate was recorded as $62.8 \%$. Therefore, apart from the services on marketing and patient management which must come first, the effect of inviting them cannot be avoided, which directly links to trust resulting from the consideration to patients.
\end{abstract}

요 약 본 연구는 산부인과 내원환자에 대한 미래경영 예측하고자 한 대학병원 의무기록정보통계를 활용하여 외래 환자, 입원환자 및 분만관련 자료를 분석한 결과 다음과 같다. 신환환자의 경우 평균 140.9 명 이었며, 각 연도가 증가 함에 따라 유의하게 감소하는 경향을 보였으며( $\mathrm{p}=0.000)$, 최초년도(2001)에 212.6명이던 것이 최종년도(2007)에는 80.9 명으로 약 140 여명의 환자가 감소하였다. 입원 실인원의 경우 평균 124.6 명 이었며, 각 연도가 증가함에 따라 유의하 게 감소하는 경향을 보였으며( $\mathrm{p}=0.000)$, 최초년도(2001)에 144.6명이던 것이 최종년도(2007)에는 104.8명으로 약 40여 명의 환자가 감소하였다. 입원환자 특성 및 분만관련 요인 등의 변수를 독립변수로, 입원환자수를 종속변수로 하여 다중회귀분석을 실시하였다. 그 결과, 입원환자수에 영향을 미치는 요인으로는 신환, 연인원 분만수 등이 선정되었으 며 이들의 설명력은 $62.8 \%$ 이었다. 이상과 같은 결과 병원은 마케팅보다 환자관리라는 서비스가 우선되어야 하지만 환자 유인 효과도 현재 무시할 수 없으며 이는 환자의 병에 대해 관심을 써주는 병원의 배려가 신뢰로 연결될 수 있 을 것이다.

Key Words : Gynecology, Hospital management, Patient secession

*Corresponding Author : Kim Kwang-Hwan(kkh@konyang.ac.kr) 


\section{Introduction}

Due to the recent opening of medical service market, threat of entry in prominent foreign medical services and major medical policies such as seriously low birth rates have totally changed the management condition in medical services. Also, as the competition between hospitals and doctors offices get intense, the managers of the medical services field are facing a major difficulty[1]. The recent medical market has changed into buyer's market in which the customers; patients select the medical institutions, and the patients, as the customers, tend to select the medical institute based on the level of medical teams in the center of medical services[2]. In particular, the hospitals are planning the future vision and strategic ways to accomplish a better result of management, recognizing the importance of hospital management just like other enterprises[3]. Noticeable amount of decrease has been shown in the area of gynecology. and according to Korea Gynecology Medical Association, the sales has decreased about $30 \%$ so far. To make things worse, the sales is more likely to decrease in the upcoming year[4]. In addition, due to the phenomenon of avoiding to have delivery in hospitals in the society, the decrease of the number of patients in gynecology area comes as no surprise. Many of the hospitals suffered a heavy blow due to lack of operation rate within the hospital, which often leads them to open into other fields[5]. They would leave their field of studies and turn into aesthetics or cosmetic surgery field, or get rid of delivery section and make the most use of gynecology. This kind of development could actually be an advantage for surgeons, but in broader term, it would create a concern of bigger series of problems. If the delivery section is decreased, the condition of delivery is also likely to become worse, which can promote even lower rate of childbirth rate. As you can see, it should not be limited to a temporary measure of current situation but a solution to fundamental problem. In the gynecology area of delivery, the number of patients are decreasing due to the lower delivery rate, as well as the rate of Caesarean section. Along with The entry of women in public affairs has gradually extended the ages of women having delivery. Therefore, to decrease the risk of natural delivery, Caesarean section is being performed for the most part. The cause can be found in the perspective of medical services suppliers and the cause of marketing. However, as the recent computerized business due to the settlement of account within those medical institutions is being promoted, each of the medical institution does not make full use of related to hospital management although they possess tremendous amount of sources apart from the purpose of materials being generated. We have summarized these medical informations and sources, and it is suggested that the decision of opinions and solution must be made on its way. During this process, a matter of primary concern would be the prediction of inpatients. If this prediction can be made accurately, then we will be able to come up with the best solution to minimize the loss by planning in a logical way. However, the prediction is made based on future circumstances, so we cannot say that certain situation would actually occur. Therefore, in this research we tried to make the best use of basic prediction source of future hospital management based on the analysis of outpatients, inpatients and delivery related information in gynecology area, on the basis of a university hospital's medical information record data.

\section{Subjects and Method}

\subsection{Subjects}

A group of people were collected based on the medical information record of a university hospital, on the year of 2001, 2004, and 2007.

\subsection{The Variables used for this Research}

For the variables used for this research, we have used the collected method from hospital evaluation[6], Kim, Kwang-Hwan[7-9] and etc. The detailed contents of extracted materials are as follows. For the variables representing general characteristics, we have researched it annually, monthly, and per seasons. The year was classified as in 2001, 2004, and 2007, and for the months, we used January to December. Lastly the season was classified as "spring", "summer", "fall", and "winter". For the cause of related number of patients, we have researched the new patients, first examination, re-visit, outpatient, number of patients in hospital rooms, and 
number of days in the room. The new patient describes the patient who has visited the hospital for the first time, and first examination is the first visited patient into examination department. Re-visit stands for the patient who has visited the same examination department 2 times or more.

The number of patients in the hospital rooms describe how many people are staying in the rooms, and the number of days in the room refers to how many days each patient stayed in the room. For the variable related to delivery, there were 11 categories including number of delivery, number of Caesarean section, and the number of sterility.

\subsection{Processing the Material and Analysis}

We have used SPSSWIN(ver 14.0) program for the source and analyzed the result in data. The phase showing changes in the gynecology patients during the 6 years have been expressed by its frequency, percentages and annual range of differences. To be able to look for the relations regarding general characteristics, patient related cause and delivery related cause, we have performed a multiple regression analysis. All significance level of data was at $\mathrm{p}<0.05$.

\section{Research Result}

\subsection{Annual Characteristics of Outpatients}

The phases of change in gynecology area of outpatient per year is described in [Table 1]. In case of new patients, the number was 140.9, and as the year increases, it shows a tendency to decrease $(p=0.000)$, and on the first year (2001), the number of 212.6 but in the final year of 2007 , it was 80.9 , showing 140 decreased patients. The average number of patients coming in for the first examination was 265.7, and it showed a tendency to increase significantly as time goes by $(\mathrm{p}=0.000)$. During the first year (2001) there were 211.6 patients in average, but it has increased up to 306.3 by the last year (2007), with 100 more patients. For the patients who are re-visiting, the number was 728 in average, but it has decreased significantly afterwards $(\mathrm{p}=0.000)$. The number of 779.3 patients in average during the year of 2001, has increased up to 688.5 during the last year 2007, which shows approximately 100 less patients. The number of patients in the room showed the record of 1,134 in average, and it has decreased significantly as the year goes up ( $p=0.001$ ). During the first year of 2001, there were 1,203.6 patients but during the last year of 2007, it has increased to $1,075.7$, showing approximately 140 less patients.

\subsection{Annual Characteristics of Outpatients}

The annual characteristics of the patients in the room can be found in [Table 2]. The actual number of patients in the room was 124.6 in average, and it showed a tendency to decrease after each year $(p=0.000)$, During the first year of (2001), the number was 144.6, but it has changed to 104.8 patient during 2007 , with approximately

[Table 1] Annual Characteristics of Outpatients

\begin{tabular}{ccccccc} 
& \multicolumn{1}{c}{} & & \multicolumn{2}{c}{ Unit : Mean \pm S.D } \\
\hline Outpatient & 2001 & 2004 & 2007 & Average & F & p-value \\
\hline New & $212.6 \pm 34.7$ & $129.1 \pm 21.2$ & $80.9 \pm 14.7$ & $140.9 \pm 60.3$ & 85.427 & 0.000 \\
First examination & $211.6 \pm 23.1$ & $279.2 \pm 23.1$ & $306.3 \pm 45.9$ & $265.7 \pm 51.2$ & 26.807 & 0.000 \\
Re- visit & $779.3 \pm 54.9$ & $716.4 \pm 29.9$ & $688.5 \pm 41.6$ & $728.1 \pm 57.1$ & 13.790 & 0.000 \\
Number of patient & $1203.6 \pm 83.2$ & $1124.8 \pm 61.1$ & $1075.7 \pm 93.7$ & $1134.7 \pm 94.7$ & 7.708 & 0.002 \\
\hline
\end{tabular}

[Table 2] Annual characteristics of inpatients

\begin{tabular}{|c|c|c|c|c|c|c|}
\hline inpatients & 2001 & 2004 & 2007 & Average & $\mathrm{F}$ & p-value \\
\hline Actual Number & $144.6 \pm 16.1$ & $122.8 \pm 10.7$ & $104.8 \pm 16.5$ & $124.6 \pm 21.8$ & 22.066 & 0.000 \\
\hline Annual Number & $675.3 \pm 78.8$ & $608.2 \pm 61.6$ & $611.8 \pm 94.2$ & $631.8 \pm 83.1$ & 2.721 & 0.081 \\
\hline
\end{tabular}


40 less patients.

For the annual record, the average was 631.8 , and it showed a tendency to decrease each year. During the first year of 2001, the number was 675.3 but it decreased to 611.8 patients in the final year of 2007 .

\subsection{The Annual Delivery related Characteristics}

The change of annual gynecology delivery related phase is shown in [Table 3]. The number of delivery was 54.5 in average, and as each year increases, it showed a tendency to decrease noticeably. $(\mathrm{p}=0.000)$. During the first year of 2001, 72.7 patients decreased to 38.9 during the last year, showing approximately 30 less patients.

For the Caesarean section, the number was 26.7 in average, but after each year it decreased significantly $(p=0.000)$. During the year of 2001, the number was 36.3 , but during the last year of 2007, it showed the record of 18.7 patients, showing about 20 patients have decreased.

In case of infertility, the number was 1.9 in average, but the rate has decreased after each year, and during the first year the number was 2.0 in average, but it has decreased to 1.9 patients in 2007

\subsection{The analysis on relation of inpatients in gynecology parts Analysis of relations}

The correlations on inpatients in gynecology

area is shown in [table 4]. The first examination has shown an inverse correlation with first time patients $(\mathrm{r}=-0.655, \quad \mathrm{p}<0.001)$, and re-visiting patients showed the parallel correlation with the new patients $(r=0.730, p<0.001)$.

For the number of outpatients staying in the room, the new patients $(\mathrm{r}=0.722, \mathrm{p}<0.001)$ and revisiting patients $(r=0.926, p<0.001)$ are positively correlated as well as the number of people staying in the room to the new patients $(\mathrm{r}=0.792, \quad \mathrm{p}<0.001)$, revisiting patients $(\mathrm{r}=0.695$, $\mathrm{p}<0.001)$, outpatients $(\mathrm{r}=0.708, \mathrm{p}<0.001)$, but negatively correlated with the patients getting first examination $(\mathrm{r}=-0.397, \mathrm{p}<0.01)$

For the days of stay, the new patients $(r=0.451$, $\mathrm{p}<0.001)$, revisiting patients $(\mathrm{r}=0.482, \quad \mathrm{p}<0.001)$, outpatients $(\mathrm{r}=0.608, \mathrm{p}<0.001)$ and number of patients $(\mathrm{r}=0.712, \mathrm{p}<0.001)$ all showed the correlation in each of the categories below.

\subsection{The factors which affect the number of inpatients in gynecology}

[Table 3] Annual Delivery related Characteristics

\begin{tabular}{ccccccc}
\hline & \multicolumn{1}{c}{} & \multicolumn{3}{c}{ Unit : Mean \pm S.D } \\
\hline Outpatient & 2001 & 2004 & 2007 & Average & F & p-value \\
\hline Number of delivery & $72.7 \pm 11.1$ & $51.9 \pm 12.5$ & $38.9 \pm 7.2$ & $54.5 \pm 17.4$ & 31.538 & 0.000 \\
Caesarean Section & $36.33 \pm 4.5$ & $25.0 \pm 5.8$ & $18.7 \pm 5.1$ & $26.7 \pm 8.9$ & 36.077 & 0.000 \\
Infertility rate & $2.0 \pm 1.1$ & $1.8 \pm 1.3$ & $1.8 \pm 2.1$ & $1.9 \pm 1.5$ & 0.045 & \\
\hline
\end{tabular}

[Table 4] Correlations of Inpatients in Gynecology area

\begin{tabular}{|c|c|c|c|c|c|c|c|c|}
\hline Category & New & $\begin{array}{l}\text { First time } \\
\text { examination }\end{array}$ & Re-visit & $\begin{array}{l}\text { Days of } \\
\text { stay for } \\
\text { outpatients }\end{array}$ & $\begin{array}{l}\text { Number of } \\
\text { patients in } \\
\text { the room }\end{array}$ & $\begin{array}{c}\text { Days of } \\
\text { stay for the } \\
\text { patients }\end{array}$ & $\begin{array}{c}\text { Number of } \\
\text { delivery }\end{array}$ & $\begin{array}{l}\text { Number of } \\
\text { C-section }\end{array}$ \\
\hline First examination & $-0.655^{* *}$ & & & & & & & \\
\hline Re-visiting patients & $0.730 * *$ & -0.261 & & & & & & \\
\hline Days of stay for outpatients & $0.722 * *$ & -0.033 & $0.926 * *$ & & & & & \\
\hline Number of inpatients & $0.792 * *$ & $-0.397^{*}$ & $0.695 * *$ & $0.708 * *$ & & & & \\
\hline Days of stay for the inpatients & $0.451^{* *}$ & 0.056 & $0.482 * *$ & $0.608 * *$ & $0.712 * *$ & & & \\
\hline Number of delivery & $0.763 * *$ & $-0.647 * *$ & $0.495^{* *}$ & $0.411^{*}$ & $0.751 * *$ & $0.337 *$ & & \\
\hline Number of C-section & $0.780 * *$ & $-0.644^{*}$ & $0.463 * *$ & $0.427 *$ & $0.731 * *$ & $0.352 *$ & $0.928 * *$ & \\
\hline Number of Infertility & 0.150 & 0.125 & 0.231 & 0.303 & 0.287 & 0.229 & 0.263 & 0.305 \\
\hline
\end{tabular}


[Table 5] The factors which affect the number of inpatients in gynecology

\begin{tabular}{lccccc}
\hline \multicolumn{1}{c}{ Category } & $\mathrm{B}$ & Std.Error & Beta & $\mathrm{t}$ & $\mathrm{p}$-value \\
\hline New & 0.115 & 0.042 & 0.316 & 2.743 & 0.010 \\
Number of patients & 0.118 & 0.021 & 0.449 & 5.670 & 0.000 \\
Number of delivery & 0.450 & 0.137 & 0.359 & 3.283 & 0.002 \\
& \multicolumn{7}{c}{ (Constant: B 83.618, $\mathrm{R}^{2}: 0.628$ ) } \\
\hline
\end{tabular}

The factors which affect the number of inpatients in gynecology area is described in table 5. To be able to find out the elements which affect the number of patients in 2001 and 2007, we have performed multiple regression analysis by setting the characteristics of inpatients and delivery related factors as independent variable, and the number of patients as dependent variables. The result showed that some of the factors which affect the number of patients were the new patients, and the number of delivery, and the reliability is $62.8 \%$

\section{Conclusion and Discussion}

Everyone is aware of the fact that Korea's birth rate is continuously decreasing. The birth rate of women in Korea has decreased from 6.0 in 1960 to 2.1 in 1983, which is one of the lowest birthrates among the world[10].

The result of this research shows the significant cut down on the number of new patients, changing from 212 patients in the year of 2001 to 80 patients in 2007, with the decrease of 150 patients. The number of patients for the first time examination, and revisiting patients have decreased as the year passed by, in 6 years of chronological phase.

The medical institutions are considering to make the best use of given source in the hospital, which is the medical ability, to shorten the waiting time and make it available for the patients to receive medical treatment whenever the patients want to.

Especially, by applying the medical appointment system in operation, they have come up with a solution to shorten the long waiting time due to unbalanced number of people in different days, dates, and time period, putting effort to increase the patient satisfaction.

In this research, the cause of the significant difference on the distribution of actual and annual number of patients mostly showed decrease after each year, since the first year of 2001 to last year of 2007.

Compared to last year, when 466000 babies were born, in this year, the birth rate was decreased by $5.5 \%$. The low birthrate is closely related to economic situation and financial burden. Lack of government support has been added to this kind of circumstances, causing the low birthrate in Korea. Experts say if the tendency of low birthrate continues, the population for production will decrease which will eventually give severe blow to the whole economy.[4]. However, the physician offices of gynecology previously existed for mostly deliveries, but nowadays it is changing into a type of medical institution where they would only accept the outpatient or minimize the previous rooms due to the extension of medical insurance benefits. Also, in case of physician offices, the patients prefer a place with good systems and trustworthy. The media frequently provides up to date informations related to medical science, and the medical consumers have higher level of medical understanding which made them prefer the medical institutions with the best systems, instead of selecting the institutions considering their seriousness of illness, systems or their positions. Also in gynecology area, most of the patients who are suffering from the pain in the lower part of the stomach are likely to be examined not only in gynecology area but in other department of the medical institution. Therefore, many patients who have transferred from other part of the medical department are also considered one of the factors.

The number of delivery among the research target, decreased significantly from 72 patients in 2001, to 38 in 2007, showing 30 decreased patients. The number of $\mathrm{C}$-section decreased noticeably by approximately 10 , from 36 patients in 2001, to 26 patients in 2007. The gynecology department is also going through the changed of increased C-section in addition to decreased delivery rate due to falling birthrate[11]. With the increased number of career women, the ages of pregnant women are 
gradually becoming older as well[10]. Therefore, in order to decrease the risk of natural delivery, a lot of C-section operations are being performed. We can also find the reason in the perspective of medical suppliers and marketing factor. After thoroughly interviewing the gynecologist, one of the reasons why the doctor prefers to perform C-section was because of convenience. The doctors are having a hard time waiting for long labor pain of the women giving birth to a child, due to lack of time or lack of doctors in the same department, making it hard to perform examination in the next day if it lasts until the nighttime. According to the data, in the medical markets, as the competitions among the doctors get intense, income per capita is also likely to decrease for each individual doctors, so the rate of competition would also affect the rate of $\mathrm{C}$-section delivery. As you can see, the behavioral factors of the patients need to be taken care of throughout special marketing skills, in order to expand the number of patients and for the management in the major hospitals and general hospitals rather than the physician's offices[12]. In addition to expanding the number of patients, the biggest issue of hospital's patient management is to prevent the secession of the patients, which makes it a major point in the perspectives of medical services and hospital management. The hospital should perform the services of patient management rather than the marketing strategy, but we cannot bypass the effect of keeping the inpatients in the hospital, which can only be done by putting a lot of effort to take care of the patient's illness, showing consideration that eventually leads to trust.

\section{Reference}

[1] Hye Jung Chang, Young Dae Kwon, Bo Ra Han, Han Hae Kim. The Expected Role and Competency of Graduates Majored in Health Services Management. Korea Society of Hospital Administration, 9(2): pp.128-148, 2004.

[2] Chung-Kul Rye. The Causality between the Number of Medical Specialists and the Managerial Performance in General Hospitals. Korea Society of Hospital Administration, 13(4): pp.1-26, 2008.

[3] Eun-Ju Jeon, Kwang-Hwan Kim. A Research on the
Total Emergency Room Time for Child Patients under 14 years suffering from External Injuries using Medical Information. Korea Society of Hospital Administration, 13(4): pp.27-45, 2008.

[4] http://www.rihp.re.kr/info/broadcast_read.asp?idx

[5] Yong-Ha Kim, Kwang-Hwan Kim. A Study on the disease pattern and current status of geriatric inpatients who are over 60 years of age through the Canonical Correlation. The Korea Academia-industrial cooperation Society, 10(2): pp.432-437

[6] Guidelines for hospital evaluation programme. Ministry for Health, Wwelfare and Family Affairs 2007; 264

[7] kwang Hwan Kim, A study on statistics for internal disease using Health Medical Information. Journal of the Korean Data Analysis Society. 9vol. 2233-2243, 2007.

[8] Kwang Hwan Kim, Yong-Ha Kim, Sang-Tae Han, Hyunchul Kang, A Study on Features of Patients Died within 48 Hours by Using Hospital Information. Journal of the Korean Data Analysis Society 9vol. 1653-1659, 2007.

[9] Kwang Hwan Kim, Sang-Tae Han, Hyunchul Kang. A Study on Finding of Hospitalization at Obstetrics and Gynecology Emergency Center by Using Health Information. Journal of the Korean Data Analysis Society. 8권 989-996, 2006.

[10] Young Nam Kim, Young Mi Kang, Min Kyung Gil, Sung Yong Kim, Dae Hoon Jeong, Kyung Bok Lee, Moon Soo Sung, Ki Tae Kim. Chronological Pattern of the Frequencies and Indications for Cesarean Section-Analysis of 6,051 Cesarean Section Cases at Busan Paik Hospital for 24 Years, 1980-2003Korean Journal of Obstetrics and Gynecology. 48(9): 2080-2090, 2005.

[11] Su Jin Park, Yong Ho Lee, Kyoung A Kim, Sang Ki Hong, Su Kyung Baek, Ho Jun Lee. Effective factor of vaginal birth after cesarean. Korean Journal of Obstetrics and Gynecology. 52(1): 23-28, 2009.

[12] Kwang-Hwan Kim. A Study on Characteristics of Prematurely Discharged Patients and Establishing a Model for Predicting Prematurely Discharged Patients . Department of Public Health Graduate School, Keimyung University, 2001. 


\section{Kwang-Hwan Kim}

[Regular member]

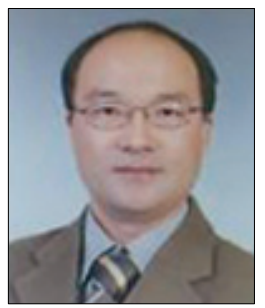

- Feb. 2001 : Department of Public Health Graduate School, Keimyung University

- Mar. 2006 Current : Assistant Professor, Department of Hospital Management, konyang University

$<$ Research Interests $>$

Medical Information, Hospital Management, Health Care 